\title{
The Use of Orthography to Increase Young Learners' Basic Literacy: Spelling Ability
}

\author{
HG Retno Harsanti \\ hildegardis.harsanti@gmail.com \\ Universitas Atma Jaya, Jakarta
}

\begin{abstract}
The mastery of literacy skills of young learners is essential and fundamental which include reading and writing. Literacy skills are closely related to cognitive abilities that provide knowledge, information, and meaning. Spelling ability is one of the essential skills in reading that must be considered. This study aims to examine the use of orthography to improve the ability to spell in reading. This study was conducted with a qualitative approach through a systematical review method with meta-synthesis as the analysis tool. Data obtained from 4 previous research articles with criteria Q1 Scopus index. The results showed that orthography could improve young learners' spelling ability.
\end{abstract}

Keywords: orthography, literacy, spelling, reading

\section{INTRODUCTION}

Literacy skills are essential and fundamental skills for everyone to have and must be nurtured from an early age. The mastery of literacy skills has become a concern of Education for All (UFA) and the United Nations (UN) as the basis for the development of quality human resources globally since 2015 . What is quite concerning is that Indonesia's literacy ability for reading is at 72 out of 78 countries studied by the Program for International Students Assessment (PISA) conducted by Organization for Economic Cooperation and Development (OECD) in 2018. This evaluation shows that specifically in Indonesia, literacy must still be taken seriously.

Pentury (2017) explained that literacy comes from the Latin "littera", which means the letter. Literacy is closely related to language and the ability to use the language both verbally and in writing (Arsa, 2019). Basic literacy skills include writing and reading, which involve the process of perceptual and conceptual decoding in which the meaning of words occurs and results in understanding or ideas which then become a source for obtaining information about the text and context of reading micro and macro (Musfiroh and Listyorini, 2016). Arsa (2019) also explained that literacy requires a series of cognitive abilities, written and oral language knowledge, knowledge of genres, and cultural knowledge, in the sense that complex abilities are needed in literacy.

Early literacy skills are the knowledge, attitudes, and skills of an early childhood that is related to reading and writing before mastering formal abilities at school age, one of which is phonological awareness that is reflected in spelling ability (Hapsari, Ruhaena \& Pratistis, 2017). Specifically, reading as a visual process involves the process of translating symbols into sounds, so reading ability is the ability to pronounce and understand written symbols through 
sensory processes and memories (Saadah \& Hidayah, 2013). Students who are unable to read well will have difficulty in participating in learning activities (Rahim, 2008) and will have difficulty in capturing and understanding the information presented in various textbooks, supporting material books, and written learning resources that are others (Abidin, 2010).

Realizing the importance of basic literacy skills for children, especially the ability to read, teachers need to use appropriate methods to teach it. Hence, this study aims to analyze the use of orthography to increase students' literacy skills in terms of spelling ability.

\section{REVIEW OF RELATED LITERATURE}

\section{Spelling}

Spelling is one of the stages of reading ability. There are two stages of early reading skill, first is the partial alphabetic phase (ages 4-6 years), and second is complete alphabetical phase (ages 5-7 years). Partial alphabetical phase is a condition where the child uses the knowledge of letters and their sounds, usually the first letters or end letters, to guess the sound of a word. While the complete alphabetical phase occurs when children read words by voicing letters and remembering them in memory and involving phonological awareness, working memory, and accessing voice codes from long-term memory (Agustina, 2014).

Phonological processing ability is the ability to process the relationship between the sound of letters (phonemes) and the shape of letters (graphemes). Phonological processing capabilities consist of phonological memory, phonological naming, and phonological awareness. Among these three aspects, phonological awareness is believed to be the most influential factor in decoding and spelling abilities (Stratman and Hudson, 2005). The phonological awareness aspect is considered very important in the process of decoding languages with complex spelling systems such as English. It is because English has a very inconsistent spelling system (Agustina, 2014).

\section{Orthography}

Orthography is one of the methods of learning English that use spelling as the strategy to help students to be able to store letter in long-form through exposure to, experience with the written or printed words (Ouellette \& van Daal, 2017). Orthographic processing ability is the ability to understand orthographic forms in a language system (Agustina, 2014). Orthography is a language writing system that involves the use of symbols in learning to facilitate reading, obtain information so that the reader is motivated to read and write (Baird \& Klamer, 2006). In line with that, Agustina (2014) explained that orthography is the ability to understand orthographic forms in a language system that is the relationship between writing and spelling in a language.

Porpodas (2006) explained that there are two types of orthography, namely shallow and deep. Shallow orthography uses phonological information in processing words and obtaining information. In contrast, deep orthography uses morphological information from the visual orthographic structure of written words in word processing and obtaining knowledge (2005). Baird and Klamer (2006) explained that in the preparation of orthography must pay attention to several things based on the characteristics of the subject of the learner. First, symbols used in language systems must have a sound to be easily read. Furthermore, the orthographic 
compilation must also decide whether the spelling formed must be phonemic or morphemic (Baird and Klamer, 2006).

\section{METHOD}

This study was done using qualitative approach through a systematical review method with meta-synthesis as the analysis tool. This method aims to identify, evaluate and construe several relevant study results related to certain issues, research questions, or phenomena (Kitchenham, 2004). There are several procedures taken in this study. First, collecting 8 articles relating to the use of orthography for spelling, which limited with criterion on Scopus indexed in Q1 level. Second, examine the abstract to ensure that the articles are met the criteria and decided to use only 4 articles with a more specific scope, which is specific on the use of orthography for young learners spelling ability in learning English. Lastly, it examines the use of orthography in each article and the results on children's spelling ability.

\section{FINDINGS AND DISCUSSION}

The orthography used in all articles was done through the use of spelling in the process of learning the introduction of letters to words. The study conducted by Ehri (2014) also applied written words which were then spelled out, while the study conducted by Ricketts, Bishop, and Nation used nonwords combined with images as the learning resources. When the children were given the task of matching, the results showed that the children could integrate pictures with their exact meanings (2009). Similarly, Ganske (1999) applied strategy involving read aloud and re-read for each of the words that have been determined based on a certain level of difficulty. Specifically, Varnhagen, Boechler, and Steffler (2009) focused on the spelling of ambiguous vowels, so they prepared choice words that have one ambiguous vowel.

Four previous studies have analyzed the use of orthography, and the results showed that orthographic could improve children's language literacy abilities. The articles include an analysis of the abilities of children in different ages start form grade 1 to 8 . The results of the analyzed articles showed that there are some similarities in the benefits obtained for student English language literacy. These benefits can be seen in table 1 and will be explained below.

Table 1. Summary of articles data

\begin{tabular}{llll}
\hline Year & \multicolumn{1}{c}{ Researcher(s) } & \multicolumn{1}{c}{ Title } & \multicolumn{1}{c}{ Subject } \\
\hline 2014 & Linnea C. Ehri & $\begin{array}{l}\text { Orthographic Mapping in the } \\
\text { Acquisition of Sight Word Reading, } \\
\text { Spelling Memory, and Vocabulary } \\
\text { Learning }\end{array}$ & $\begin{array}{l}\text { Students in grade 2 and 5 } \\
\text { (discussed from Rosenthal } \\
\text { and Ehri, 2008) }\end{array}$ \\
2009 & $\begin{array}{l}\text { Connie K. Varnhagen, } \\
\text { Patricia M. Boechler \& }\end{array}$ & $\begin{array}{l}\text { Phonological and Orthographic } \\
\text { Influences on Children's Vowel } \\
\text { Dorothy J. Steffler }\end{array}$ & $\begin{array}{l}\text { Spelling } \\
\text { Jessie Ricketts, Dorothy V. } \\
\text { M. Bishop, and Kate Nation }\end{array}$ \\
& $\begin{array}{l}\text { Orthographic facilitation in oral } \\
\text { vocabulary acquisition }\end{array}$ & $\begin{array}{l}\text { Students in grade 1-3 } \\
\text { Children aged 8-9 (around } \\
\text { grade 2-4) }\end{array}$
\end{tabular}




\section{Spelling Ability}

The ability to spell was found to be increased through the orthography in all four studies. This skill is the easiest to find, given that orthography itself is a method that uses spelling as its strategy. All children were exposed to spelling so that their spelling ability is automatically boosted. Ehri (2014) explained that the students are given some words that involved the pronunciation of words, word definitions, and use of words in sentences, all of which were described in flashcards. The results of his study showed that children are better at spelling when given words that are whole rather than partial letters because they can connect the spelling with the pronunciation (Ehri, 2014).

Ricketts, Bishop, and Nation (2009) use the help of nonword - picture matching in orthography implementation. Before the use of orthography in the learning process, the students' spelling ability was relatively low. After being given teaching with orthography, there was an enhancement on the students' spelling ability. There were 12 nonwords containing four or five letters and three or four phonemes for the experiment. Then every student were exposed to 6 non words in two different ways, first without orthography and the second with orthography. Ricketts, Bishop, and Nation (2009) in their study found that the use of orthography improve students' ability to produce target spelling pattern although they are not familiar with the words. Even in the second session, when learning involves novel as a learning tool, students are able to make spelling sounds better that are consistent with previous orthography teaching. (Ricketts, Bishop, and Nation, 2009).

Ganske (1999), in his research, applied several stages of activities in learning including reading words, using words in sentences, and re-reading the words that have been given, and encouraging students to write responses to several words determined by the teacher. The results of his research showed that there is an enhancement in the ability to spell in children with certainty and consistency. However, this enhancement is also influenced by age. The results also show that students still make some mistakes, such as those in grades 6-8. They sometimes wrongly reverse the order of letters and difficulties with affricates, but this is a characteristic pattern of error called the Common Development Perspective. In his conclusion, Ganske (1999) suggested that teachers must understand individual student's orthography knowledge in order to be able to provide teaching that is in accordance with needs.

Children are often wrong in saying vowels because of high ambiguity, where one vowel can have several different pronunciations. In their research, Varnhagen, Boechler, and Steffler (2009) prepared 25 four-letter, one-syllable nonwords, with 16 target items and nine forms to prevent decisions based on similar nonwords, which have one ambiguous vowel. The results of the study indicated that the use of orthography can improve the correct vocal pronunciation of the words specified. Children who have knowledge of orthography showed better ability to spell the right vowel rather than children who do not have orthography knowledge or lack understanding of orthography (Varnhagen, Boechler, and Steffler, 2009). 


\section{CONCLUSION AND SUGGESTION}

From the whole description above, it can be concluded that orthography is useful in teaching language literacy for young learners, especially in the topic of spelling ability. The right stimulus needs to be given to children to be able to give the correct spelling response. Understanding orthography also helps children become more sensitive to the spelling of new words that they have never even heard of before. Unfortunately, there is a research gap that arises from the four studies examined in which children who were subjected to research consisted of various ages. Hence, the results of the study may not be accurate due to the differences in participants' ages, for every age stage of learners may have different learning challenges.

The suggestion that can be given for teaching teachers is essential to know the level of understanding of students' orthography, so that the teacher can provide the right learning stimulus. Students also need to understand orthographic knowledge to be more sensitive to learning to spell. For further researchers, it is recommended to examine the use of orthography in children of the same age level so that it can provide a more accurate picture.

\section{REFERENCES}

Abidin, Y. (2010). Strategi membaca teori dan pembelajarannya. Bandung: Rizqi Press.

Agustina, M. (2014). Pengaruh phonological awareness dan kemampuan pemrosesan ortografi terhadap kemampuan membaca awal siswa sekolah dasar. Modeling: Jurnal Program Studi PGMI, 2(2). https://doi.org/10.2345/jm.v1i2.735

Arsa, D., Atmazaki, A., \& Juita, N. (2019). Literasi awal pada anak usia dini suku anak dalam Dharmasraya. Jurnal Obsesi : Jurnal Pendidikan Anak Usia Dini, 3(1), 127136-136. https://doi.org/10.31004/obsesi.v3i1.159

Baird, L., \& Klamer, M. (2006). Persoalan Ootografi dalam bahasa daerah di Alor dan Pantar. Linguistik Indonesia, 24(1), 35-57.

Ehri, L. C. (2014). Orthographic mapping in the acquisition of sight word reading, spelling memory, and vocabulary Llarning. Scientific Studies of Reading, 18(1), 5-21. https://doi.org/10.1080/10888438.2013.819356

Ganske, K. (1999). The developmental spelling analysis: A measure of orthographic knowledge. Educational Assessment, 6(1), 41-70. https://doi.org/10.1207/S15326977EA0601_4

Hapsari, W., Ruhaena, L., \& Pratisti, W. D. (2017). Peningkatan kemampuan literasi awal anak prasekolah melalui program stimulasi. Jurnal Psikologi 44(3), 177-184.

Kitchenham, B. (2004). Procedures for performing systematic reviews. Eversleigh: Keele University.

Musfiroh, T., \& Listyorini, B. (2016). Konstruk kompetensi literasi untuk siswa sekolah dasar. LITERA, 15(1), 1-12.

Organization for Economic Cooperation and Development. (2018). PISA Result 2018.

Ouellette, G., \& van Daal, V. (2017). Introduction to the special issue. Orthographic learning and mental representations in literacy: Striving for a better understanding of a 
complex lead role. Scientific Studies of Reading, 21(1), 1-4. https://doi.org/10.1080/10888438.2016.1254635

Pentury, H. (2017). Pengembangan literasi guru PAUD melalui bahan ajar membaca, menulis dan berhitung di Kecamatan Limo dan Cinere. Jurnal Pengabdian Kepada Masyarakat, Dikemas, 1(1), 14-21.

Porpodas, C. (2006). Phonology and literacy acquisition in deep and shallow orthographies. In Handbook of Orthography and Literacy (p. 189). New Jersey.

Rahim, F. (2008). Pengajaran membaca di sekolah dasar. Jakarta: Bumi Aksara.

Ricketts, J., Bishop, D. V. M., \& Nation, K. (2009). Orthographic facilitation in oral vocabulary acquisition. The Quarterly Journal Of Experimental Psychology, 62(10), 1948-1966. https://doi.org/10.1080/17470210802696104

Saadah, V. N., \& Hidayah, N. (2013). Pengaruh permainan scrabble terhadap peningkatan kemampuan membaca anak disleksia. Empathy Jurnal Fakultas Psikologi 1(1), 39-52.

Strattman, K., dan Hodson, B. W. 2005. Variables that influence decoding and spelling in beginning readers. Journal Child Language Teaching and Therapy, 21, 165.

Varnhagen, C. K., Boechler, P. M., \& Steffler, D. J. (2009). Phonological and orthographic influences on children's vowel spelling. Scientific Studies of Reading 3(4), 363-379. 